Ема Петровић

Катедра за оријенталистику

Универзитет у Београду

Филолошки факултет

ema.miljkovic@fil.bg.ac.rs

https://doi.org/10.18485/ai_gozik.2019.ch12

821.512.161.09

\title{
НА КРАЈУ ГОЗБЕ: \\ КАФА И ЧАЈ КАО ТЕМЕ ТУРСКЕ КЮИЖЕВНОСТИ
}

Кафа је напитак који је у Европу дошао са Истока, посредством Османлија, а у књижевности се најпре јавља као предмет занимања путописаца. Чувени турски путописац Евлија Челебија, у свом путовању Балканским полуострвом, описаних у његовом чувеном путопису (тур. Seyahatnama), помиње и испијање кафе и описује кафане широм југоисточне Европе.

Са стварањем Републике Турске 1923. године и рађањем савремене турске књижевности, која је примарно посвећена темама које описују живот у последњим деценијама постојања Османског царства, као и новостворене Републике, на страницама турских романа, у свом верном приказу свакодневног живота Турака у 20. веку, срећу се помени пијења кафе.

Након проглашења Републике Турске, кафа постаје скуп увозни артикал из арапских земаља, које су се раније налазиле у границама Османског царства. Турци све више почињу да конзумирају чај, који се гаји на турским обалама Црног мора, и та промена се може уочити и у књижевности.

Кључне речи: Османско царство, турска књижевност, кафа, Евлија Челебија, кафане. 
Кафа, топла, хладна, црна, бела, турска, домаћа, бечка, ирска (и још многе друге варијанте које данас постоје), напитак у коме данас ужива готово цео свет, има своје корене на Истоку.

Пореклом из Јемена (луке Моке, одакле се извозила) или Етиопије (града Кафе), до Европе је стигла посредством Турака Османлија. Почетком 16. века кафа је била добро позната у Адену, Меки и Каиру. Иако је хаџијама овај напитак и раније био добро познат, уживање кафе у Османском царству почиње након османског освајања Египта 1517. године. ${ }^{1}$

На наше просторе кафа стиже у време владавине султана Сулејмана Законодавца (1520-1566), када је на султановом двору успостављена и служба царског кахвеџије. Уживање овог напитка прати и отварање објеката у којима се испија кафа, тзв. Kahvehana, нама добро познатих кафана (Фотић 2005: 270-285).

Постоји легенда, везана за почетке уживања кафе у Европи, и односи се на време непосредно након битке код Мохача (1526) у данашњој јужној Мађарској, у којој су се сукобиле османска и угарска војска. У овој бици су Османлије однеле победу, која је довела до нестанка Краљевине Угарске са историјске позорнице (и у којој гине угарски краљ Лајош II), а једна од последица је била и велики број заробљених угарских војника. Неки од њих, који су пуштени из османског логора, препричавали су, за њих, чудне обичаје Османлија. Између осталог, наводе како су им после оброка давали да пију „врућу, одвратну, блатњаву црну течност“, чији укус за-

1 У домаћој историографији и културологији најопсежнији текст о кафи написао је А. Фотић, у тексту „(Не)спорно уживање: појава кафе и дувана“, који је објављен у кюизи Приватни живот у српским земљама у освит модерног доба, Београд: Clio, 2005, 261-301. 
робљеним угарским војницима нимало није одговарао. Ова легенда се често јавља у западним изворима који описују Мохачку битку, али како су сви каснијег датума, није је могуће потврдити.

У литератури кафа се најпре јавља као предмет занимања хроничара и путописаца.

Исцрпан преглед записа хроничара и путописаца о уживању у кафи написао је А. Фотић у већ цитираном раду „(Не)спорно уживање: појава кафе и дувана“ (2005). Према његовим наводима, најранији опис уживања кафе на Балкану је из пера поузданог османског хроничара Ибрахима Печевије, који је деведесетих година 16. века посетио једну „богато уређену“ кафану у Сарајеву. Као непотребну новотарију и место пуно искушења, кафану помиње чувени османски учењак и кадија, Хасан Кафи Прушћак (Акхисари) у раду Тeметь мудрости о уређеть света, чије је писање завршено 1597. године у Прусцу. Један други хроничар, Абдулкадир ефендија забележио је да су османску војску утаборену на пољу поред Панчева 1598. године (током трајаға Дугог рата, Е.М.) два дана посећивале занатлије из градских дућана и кафана; Француз Лефевр је 1611. године видео кафане чак и у варошицама попут Пљеваља и Прокупља; изгледа да је почетком 17. века у Београду био и један Дубровчанин кафеџија, или трговац кафом; управо је у Београду у то време чувени мудерис, муфтија и шејх Мунири Белигради саставио кратки Спев против употребе кабе, вина, опијума и дувана, један од првих памфлета те врсте. Средином 17. века извори су пуни података о томе да су чин испијања кафе и кафана, као нова институција, којих је било и по десетак у појединим варошицама, постали део балканске свакодневице (Фотић 2005: 271-278).

Чувени турски путописац Евлија Челебија, у свом путовању Балканским полуострвом, описаних у њего- 
вом путопису (тур. Seyahatnama), помиње и испијање кафе и описује кафане у бројним балканским градовима. Тако је, на пример, овај познати путописац у Битољу побројао 40 кафана, у Сарајеву је постојало током 17. и 18. века 50-60 кафана, а у Београду у другој половини 18. века најмање 20, већином у Воденој вароши на Сави (Čelebi 1979).

Овај релативно мали број кафана у Београду мора се ставити у контекст историјских околности; наиме, овај податак је из друге половине 18. века, након аустријског повлачења из Београда којим су владали у периоду 1718-1739. године. Реално је претпоставити да су у време аустријске управе бројне кафане биле затворене, као симбол „оријенталног“, што су Аустријанци желели да искорене. Познат је податак да су у Бечу крајем 17. века постојале свега четири кафане.

Илустрације ради, навешћемо један од најбољих описа кафана у Османском царству, управо из пера добро познатог Евлије Челебије, а посвећен једној кафани у Илоку. „У том граду, у вањској тврђави“, читамо код Евлије, „пред Чаршијском џамијом налази се једна одлична кафана са лијепим видиком... С једне стране те лијепе кафане налази се одличан трговачки хан. Тај хан је као неки безистан овог шехера. Покрај њега налази се (још једна) лијепа кафана. Та кафана је на главној улици“ (Čelebi 1979: 523-524).

Овај опис показује колико је кафана као институција била значајна и у граничним пределима Османског царства, о чему сведочи њена позиција уз Чаршијску џамију и на главној градској улици.

Кафане (tur. Kahvehane) доносе и једну битну нову социјалну димензију у свакодневни живот у Османском царству. Како је муслиманима забрањено конзумирање алкохола (мада су у Османском царству постојала спорења око тог питања), они се нису окупљали у крчмама 
или механама, већ је та празнина употпуњена са почецима конзумирања кафе и отварањем кафана. Према сведочењу хроничара, оне су у Константинопољу ницале „на сваком ћошку“, па се процењује да их је већ крајем владавине Селима II седамдесетих година 16. века било око 600. У кафанама су се окупљали и нижи и виши друштвени слојеви. Занимљив је податак да је управо град „на два континента“ једини европски град у коме су своје место нашле и присталице и противници Француске буржоаске револуције 1789. године. Тачно се знало ко се окупља у којој кафани, те сукоба није било (Фотић 2005) (Shaw 1976).

Француз А. Пуле, у свом добро познатом, оштром стилу, из кога одише прекор па и презир према обичајима а ла турка, следећим речима описује припрему и испијање кафе на једном од одморишта у Херцеговини, на свом путу из Дубровника ка Мостару 1658. године:

Када се сто распреми (после јела)... сви поседају као малопре па чекају да им се донесе кафа. И веома промућуран човек тешко би распознао чега има више у тој смеси - црнила или горчине. Умешност се састоји у томе да се кафа пије из мале порцуланске шољице, али толико врућа, да је скоро немогуће држати у руци. Дивота је посматрати како они који је пију криве уста и праве гримасе - а то чине јер нема никаквог ефекта ако се кафа не пије врела. И да би ублажили врелину, они кафу срчу, задржавајући дах и производе толико чудновато гргутање да и Скарамуш, када би се могао гостити по овом турском обичају, као што се гостио камењем, та комедија би била успешнија од свих осталих игара... код њих је добро то што је ту свако лепо угошћен. Оно што ми се не свиђа јесте то што сваки дебели коњушар бива раван господину, тражи му лулу или додаје своју. И после два - три дима, даје лулу даље са гомилом своје пљувачке на њој. (Цитирано према Фотић 2005: 261) 
Са стварањем Републике Турске 1923. године и рађањем савремене турске књижевности, која је примарно посвећена темама које описује живот у последњим деценијама постојања Османског царства, а затим и новостворене Републике, на страницама турских романа, у верном приказу свакодневног живота Турака почетком 20. века срећу се помени пијења кафе.

Након проглашења Републике Турске, кафа постаје скуп увозни артикал из арапских земаља, које су се раније налазиле у границама Османског царства. Турци све више почињу да конзумирају чај, који се гаји на турским обалама Црног мора, и та промена се може уочити и у књижевности.

Тако на пример, у познатом роману Грмуша турског књижевника Решата Нурија Гунтекина, по коме је снимљена врло популарна серија, а чија се радња одвија на прелазу две епохе, османске и републиканске, читамо:

Господин, чија је једна страна браде била црна, а друга бела, викао је од беса и правио покрете као да ће да пребије послужитеља, који је стајао испред њега и сав дрхтао као ја малопре. Шољицу кафе, која је стајала испред њега, просу кроз прозор на улицу као да просипа прљаву воду. (Грмуша 125)

У истом роману, при опису догађаја током Првог светског рата и Рата за независност, нема помена кафе, иако је ратна тематика у другом плану, аутор се имплицитно не осврће на ратом измењене животне прилике.

Тако писац, кроз редове дневника главне јунакиње, иначе учитељице у једној анадолској касаби, описује школски излет:

2 Цитирани део радње романа Грмуша се одвија у предвечерје избијања Првог светског рата. 
Господин директор био је са нама на ручку... из школе је донео самовар за чај. Желео је да ми он лично спреми чај. (Грмуша 253)

У истом роману на наредним страницама читамо:

Ихсан-бег се опоравио брже него што смо се надали. Кад сам му однела чај са млеком затекла сам га обученог. (Грмуша 331)

У роману Снег турског нобеловца Орхана Памука, који је, по не баш уобичајеном Памуковом књижевном обрасцу, посвећен проблемима модерне Турске, такође се помиње испијање чаја:

И тако су ова тројица доконих младића, који су на подстрек службеника МИТ-а с орловским носем устежући се сели за њихов сто, испијајући чај што га је својим гостима послужио власник чајџинице и због тога осећао велико задовољство, уз све оно што су очекивали од војног пуча, уз своја прижељкивања и притужбе на пропале политичаре, испричали и много потказивачких трачева: о противзаконитом клању животиња, мућкама у складишту Текела, о томе како неки предузимачи камионима за месо преко Јерменије превозе и у бараке смештају раднике на црно, јер јефтиније раде, како неки терају људе да раде по читав дан и уопште им не плате... (Снег 205)

Из овог одломка је очигледно колико је и данас значајна улога чајџиница у свакодневном животу у Турској. И данас, готово да нема ситуације у којој се не пије чај. Балканским народима добро позната „турска кафа“ у Турској је постала нешто што се пије у посебним ситуацијама када се жели души угодити, или као атракција

3 Ово је један од ретких помена да се у Турској пије чај са млеком. 
за туристе. Наравно, и Турску су преплавиле све врсте „модерних“ начина припреме кафе, па ће млади Турци радо попити „еспресо“ или „инстант“ кафу. Ипак, сви они ће се увек пре определити за чај. Чај је, уз „ајран“ (врста јогурта) постао турско национално пиће, за све прилике и за свако доба дана.

У истом Памуковом роману, чија се радња дешава последњих година 20. века у граду Карсу на самој граници Турске са Русијом, Јерменијом и Азербејџаном, аутор се осврће на чињеницу да становништво тог града ретко конзумира кафу. Наводећи теме за помало стегнут разговор са старом пријатељицом, коју деценијама није видео, писац бележи:

С пролазном растерећеношћу што је створила блискост коју - макар и вештачки - једно спрам другога осете мушкарац и жена, који схвате да су рођени у истом хороскопском знаку, разговарали су о месту које су мајке имале у њиховим животима (врло кратко), како се на месту посластичарнице у којој су се нашли до 1967. године налазила православна црква а да се портал срушене цркве чува у музеју, о посебној музејској збирци посвећеној јерменском масакру (неки би туристи помислили да је тај део музеја посвећен Јерменима које су масакрирали Турци, да би потом схватили да се, напротив, ради о Турцима које су масакрирали Јермени, о једином, напола глубом а напола аветињском конобару у посластичарници, о чињенице да се у карским чајџиницама не продаје кафа, зато што је незапослени не могу пити што је скупа, о политичким гледиштима новинара који је Ка водио у обилизак... (Снег 45)

Памук нас, описујући болне сцене самоубистава младих девојака у Карсу (која су, испоставиће се, повезана са наступајућом исламизацијом Турске и юиховом распетошћу између оданости вери и забране да се мараме носе у школама, подвукла Е.П.), поново подсећа коли- 
ко је чај неизбежан део турске културе, да је његов помен нашао место и у елаборацији једне тако тешке теме:

Девојка по имену Теслиме, у својој је последњој ноћи ћутке одгледала серију Маријана и пошто је скувала чај, послужила га оцу и мајци, отишла у своју собу, узела абдест, клањала намаз, веома дуго била уронила у мисли и изговорила молитву, својом се марамом обесила о куку лустера. (Снег 28)

Овај сажети преглед завршићемо још једном реченицом турског нобеловца, која изистински одражава атмосферу турске чајџинице и још једанпут истиче место овог напитка у свакодневном животу модерне Турске:

Као и у свим другим чајџиницама, ресторанима и хотелским салама у Карсу и овде су на зидовима висиле панораме швајцарских Алпа, а не околних планина, којима су се Каршани поносили. Остарели конобар, који им је мало раније донео био чај, сео је покрај касе, међу тепсија пуне колачића и чоколадица чији су се маслац и станијој пресијавали под светлошћу бледе лампе... (Снег 49)

\section{Извори и литература}

Guntekin, Rešat Nuri. Dnevnik jedne ljubavi. Grmuša. Beograd: Čigoja, 2016. Štampano.

Pamuk, Orhan. Sneg. Beograd: Geopoetika, 2007. Štampano.

Shaw, Stanford J. History of the Ottoman Empire and Modern Turkey: Volume 1, Empire of the Gazis: The Rise and Decline of the Ottoman Empire 1280-1808. Cambridge: Cambridge University Press, 1976. Printed.

Фотић, Александар. „(Не)спорно уживање: појава кафе и дувана“. Приватни живот у српским землама у освит модерног доба. Београд: Clio, 2005. 261-301. Штампано.

Čelebi, Evlija. Putopis. Odlomci o jugoslovenskim zemljama. Sarajevo: Veselin Masleša, 1979. Štampano. 


\section{Ema Petrović}

\section{AT THE END OF THE FEAST: COFFEE AND TEA AS THE TOPICS OF THE TURKISH LITERATURE}

Coffee as a beverage in which today enjoys almost the entire world population, had its roots in the East. By origin from Yemen or Ethiopia, it had come to Europe by the Ottoman Turks. It had come on the Balkan Peninsula during the reign of Ottoman sultan Suleiman the Great (1520-1566). At the same time, had been opened the first coffee shops, at first in the capital, Constantinople, and later in the other cities and centers of the Ottoman Empire, from where it had been transferred to the Central and Western Europe.

In the literature, the coffee, as well the coffeeshops had been firstly mentioned in the travelers ' notes. One of the most famous Turkish travelers Evliya Çelebi in his book Seyahatname, where he had described, among other places, his experiences along the Balkans, had mentioned the drinking of coffee as well as the coffee shops in numerous South-East European towns.

With the establishment of the Republic of Turkey in 1923, and beginnings of the modern Turkish literature, which has been basically dedicated to the topics of the everyday life during the last decades of the Ottoman Empire and later in the Republic of Turkey, the ritual of drinking coffee has found its place on the pages of the Turkish novels.

After the proclamation of the Republic of Turkey, coffee had become very luxurious item, since from that time it had to be imported from the Arabic lands, which used to be part of the Ottoman Empire. At that time, the Turks had started to drink more tea, which they produce themselves in the waste tea growing fields on the Turkish Black Sea coast area. This change has been noted in the literature as well. 